\title{
A Study on Cadets' EFL Learning Styles Preferences: The Case of Sylhet Cadet College
}

\author{
Md. Mahbubul Alam \\ Department of English, Sylhet Cadet College, Sylhet, Bangladesh
}

Email address:

palash759@yahoo.com

\section{To cite this article:}

Md. Mahbubul Alam. A Study on Cadets' EFL Learning Styles Preferences: The Case of Sylhet Cadet College. International Journal of Language and Linguistics. Vol. 3, No. 6, 2015, pp. 474-480. doi: 10.11648/j.ijl1.20150306.32

\begin{abstract}
Learners' learning style preference is one of the vital issues in the EFL (English as a Foreign Language) arena. Different learners learn English differently. But there must be a close proximity between the teachers'preferred teaching style and the learners' favored learning style. The present study was done on 145 senior cadets of Sylhet Cadet College. The situation of English in cadets is no doubt good. But there are still some teaching systems that must be reconsidered and therefore renovated teaching styles based on cadets' style preference should be introduced. To conduct the survey a questionnaire was followed. The findings show that various cadets belong to various categories of learning style. A brief analysis of the findings is presented. Besides, this paper offers some suggestions for the teachers based on the findings of the survey.
\end{abstract}

Keywords: Auditory, Visual, Kinesthetic, Group, Individual, Inductive, Deductive, Communicative

\section{Introduction}

Learning process is, according to Stern (1983), 'overtly of strategies and techniques employed by the learner, and, covertly, of conscious and unconscious mental operations ( $\mathrm{p}$. 339)'. For language learning there is no transparent route, may it be the learner's first language or second language. It is not a simple way of experiencing something, rather it is experiencing the 'most difficult set of skills a person could ever struggle to learn (Reid 1987/1995; Dunn \& Dunn 1972; Kolb 1984; Fleming 2001; cited in Vaseghi et al 202; p. $441)^{\prime}$. That the process of language learning is complicated is more visible in the countries where English is used as a second/foreign language.

Language learning is a way where the learner 'strives and search for new experiences and challenges, to develop a feel for the language and to find opportunities for constant practice (ibid)'. Through this struggling experience the learner develops her/his individual ways of learning a language that can simply be termed as learner's learning styles. Learner adopts these learning styles to learn the language easily. In the 1970s the concept of individual learning styles gained popularity (Sprenger 2003; cited in Kara 2009; p. 77) and later on, the scholars of English Language Teaching (ELT) became more interested in learners' learning styles preference.

\section{English Language Teaching/Learning Reality in Cadet Colleges in Bangladesh}

The reality of English language teaching / learning in cadet colleges in Bangladesh is very positive. English version curriculum is followed in a cadet college. The academic atmosphere tries to ensure a context of English speaking always and everywhere. The classroom language is compulsorily English, though with some deviations sometimes in non-English courses. Cadets get good exposure to practicing English with the people of outside their institutions. But internal exposure is more remarkable and beneficial here as they are frequently facing English speaking contexts. Their participationin regular English public speaking session in front of 350 audiences is a must. They have to participate in different English writing contexts. There is a regular English pronunciation class where cadets have to participate.

In addition to this, cadet colleges are now attached to the English improvement project of the British Council. In January 2014 the British Council Bangladesh launched a two 
year English language improvement project in twelve cadet colleges across the country. Teachers of both English and non- English courses are now being trained under the British Council. They are now undergoing CiSELT and CLIL courses offered by the British Council. Sylhet Cadet College is no exception. The above mentioned English teaching / learning context is completely reflected here. Besides, here cadets' classes are fully equipped with multi-media.

\section{Literature Review}

\subsection{Learning Styles}

Different proponents of ELT (English Language Teaching) have proposed different definitions of learners' learning styles. But they inwardly share same ideas and philosophy behind language learning. According to Reid (1987; p. 89), 'Style refers to a pervasive quality in the learning strategies or the learningbehavior of an individual'. In this regard, Reid (1995, cited in Kara 2009) proposed two major hypotheses about learning styles: 1. All students have their own learning styles and learning strengths and weaknesses. 2. A mismatch between teaching and learning styles causes learning failure, frustration and demotivation. Learning style is the biologically and developmentally imposed set of characteristics that make the same teaching method wonderful for some and terrible for others (Dunn and Grigss, 1988; cited in Kara 2009). Fleming (2001) defines learning style as 'an individual's characteristics and preferred ways of gathering, organizing, and thinking about information.'

Dunn and Dunn (1979, as cited in Reid, 1987) define learning styles as "a term that describes the variations among learners in using one or more senses to understand, organize, and retain experience" (p. 89). Styles are patterns that give direction to learning behavior (Cornett, 1983; cited in Kara 2009). Learning style is generally conceived as faiths, preferences and manners used by individuals to help their learning under the classroom or environmental conditions (Borich and Tombari 1997; Hohn 1995; cited in Ramezani et al; p. 151). Learning styles arevarious approaches or ways of learning. They involve educating methods, particular to an individual, that are presumed to allow that individual to learn best. It is commonly believed that most people favor some particular method of interacting with, taking in, and processing stimuli or information (LdPride, 2009; cited in Kara 2009).

\subsection{Variables of Language Learning}

Language learners' success significantly depends on some factors that can be called variables in language learning.Language learning variables include: age, gender, motivation, intelligence, anxiety level, learning strategies and language learning styles (Sharp, 2004). Other variables include:total years of education in the native language, whetherthe learner is bilingually educated or begins education in the second language only, learner's level of cognitive development,length of time spent learning the
English language in isolation without exposure to content. These are the variables that affect the rate of English language learning of a learner.

\subsection{Different Models of Learning Styles}

Over the years scholars have presented different models of learning styles. This paper will deal with the models of Nunan, Kolb, Fleming, Reid and Dunn \& Dunn.

Nunan's Model

David Nunan (1991) classifies language learners into four categories according to the ways learners learn or expose to a language. They are: concrete learners: concrete learners are those learners who employ very direct means of gathering and processing information. They record information using their senses, i.e., sight, smell, touch, taste, and hearing. Analytical learner: analytical learners are those learners who have cognitive capability to analyze carefully and demonstrate great interest in structures. They reveal their independence by performing these things themselves. They like to study individually, find their own mistakes and work on assigned task problems. Authority-oriented: Theselearners like their teacher to explain everything to them. They tend to write everything in their notebook, prefer to study grammar rules and learn by reading. Communicative learners: Communicative learners tend to follow communicative and social learning approach. These learners prefer learning a language by watching, listening to native speakers, talking to friends in English and watching television in English. They are interested in using English outside class, learning new words by hearing and learning by conversation.

Kolb's Model

Kolb (McLeod, 2013) opines that different people adopt different learning styles. Kolb's categories are: Diverging: Learners of this category are sensitive. They prefer to watch rather than do, tending to gather information. These learners perform better in situations that require ideas-generation, for example, brainstorming.Learners with the diverging style prefer to work in groups. Assimilating: They prefer a concise, logical approach. They require clear explanation rather than practical opportunity. They are more interested in ideas and abstract concepts. Learners with this style prefer readings, lectures and exploring analytical models.Converging:

Learners with a converging learning style can solve problems and use their learning to find solutions to practical issues. They like to experiment with new ideasand to work with practical applications.Accommodating: These learners rely on intuition rather than logic. Learners with an accommodating learning style tend to rely on others for information. They prefer to take a practicalapproach. They tend to be attracted to new challenges and experiences.

\section{Fleming's VARK Model}

VARK stands for Visual, Aural, Read/Write and Kinesthetic respectively. Fleming (2001) proposed the VARK model.According to Fleming, Visual learners prefer maps, charts, graphs, diagrams, highlighters, different colors, pictures and word pictures. Aural learners like to explain new ideas to others, discuss topics with other students and their 
teachers, use a tape recorder, attend lectures etc. Read/Write learners prefer lists, essays, reports, textbooks, definitions, printed handouts, readings, web-pages and taking notes. Kinesthetic learners like field trips, trial and error, doing things to understand them.

\section{Reid's Model}

Among the scholars who have proposed several models of learners' learning style preference Reid is more well-liked and extensively cited. Reid (1995) proposed three major categories of learning styles. They are: cognitive learning style, sensory learning style, and personality learning style. Cognitive learning style is again divided into Fieldindependent and Field-dependent, Analytic and Global, and Reflective and Impulsive.Sensory learning style is also categorized as Perceptual learning style, Environmental learning style, and Personality learning style. Perceptual learning style includes Auditory, Visual, Tactile, Kinesthetic, Group, and Individual learners. Personality learning style can be classified into several learning types based on learners' personality. Extrovert learners, Introvert learners, Sensing learners, perception learners, Thinking learners, feeling learners, Judging learners, perceiving learners, Ambiguitytolerant learners, ambiguity-intolerant learners, left- brained learners, and right-brained learners.

Dunn \& Dunn's Model

According to Dunn and Dunn (1978), five stimuli groups that contain twenty one elements determine learners' learning styles. The stimuli groups are: environmental, emotional, sociological, physical, andpsychological. These stimuli groups affectlearner's learning.Environmental stimuli group consists of our elements: sound, light, temperature and design. For example, there are some learners who learn better in a quietenvironment, while some learners like to learn through listening simultaneously. The emotional stimuli group consists of motivation, persistence, responsibility, and structure elements. Sociological stimuli group includes peers, self, pairs, andteams. There are some learners who prefer to learn in a group, whereas, others like to learn individually. Physical stimuli group possesses perception, intake, time, and mobility elements. Psychological stimuli group consistsof analytic / global, right-brain / left-brain, and reflective / impulsive elements.

\subsection{Review of Different Types of Learners Based on Learning Styles}

The above-mentioned models of learning styles presented various types of learners according to their preferred learning styles. But actually their categorization of learners according to their learning styles is almost similar to each other. They share 'remarkable similarities' (Huda 2013; p. 45) in terms of the classification of learners. This paper will review the most significant categories of language learners for the convenience of the research.

Auditory Learners: Auditory learners prefer to learn a language through listening. They used to read aloud when reading the text and prefer listening lecture than reading textbook. They remember things what they hear in class better than what they read. They like to learn by watching $\mathrm{TV}$, films, etc.

Visual Learners: Visual learners learn more effectively through visual aids. They learn better by reading what the teacher writes on the board. They like to watch someone's demonstration than listening. They learn better by reading textbook than by listening to others.

Kinesthetic Learners: Kinesthetic learners learn better when they can participate in related activities and exercises. They like more to participate in role-playing than listening to lectures. They can learn better through total physical involvement.

Group Learners: Group learners prefer working with others in groups. They learn more when they study group-wise with others.

Individual Learners: Individual learners prefer to learn individually / alone. They learn more when they work alone.

Field-Independent Learners: Field-independent learners learn more successfully step by step, beginning with analyzing facts and proceeding to ideas. They also like to learn individually (Huda 2013; p. 45).

Field-Dependent Learners: Field-dependent learners learn more effectively in context and holistically. They do not like to learn a lesson step by step.

Inductive Learners: Inductive learners like to learn by following inductive method, i.e., inducing a rule or coming to a conclusion from numerous instances (Huda 2013; p. 45).For example, an inductive learner learns grammar from examples and uses in sentences.

Deductive Learners: Deductive learners like to learn by following deductive method, i.e., learning the rules first and then using them in examples.

Authority- Oriented Learners: Authority- oriented learner expects that the teacher will explain everything and will guide him directly. He writes everything in notebooks, study grammar, learn by readingand learn new words by seeing them (Islam 2011; p. 23).

Communicative Learners: Communicative learners prefer to learn in an open environment by following a communicative and social learning approach (Huda 203; p. 45). They learn by watching, listening to native speakers, talking to friends in English and watching television (Islam 2011; p. 23).

Extrovert / Introvert Learners: Extrovert learners are inquisitive and social. They want to be involved in conversation and will take every opportunity to speak. On the other hand, Introvert learners are confused about conversation, unless they find the topic interesting. Introvert learners are much more likely to be shy and hesitant speakers. But, Extrovert learners will just say what's on their mind. Mistakes are not so important to them. Extrovert learners are good enough at languages to 'learn on the street'. Introvert learners, on the other side, prefer learning methods where they can study alone. (Retrieved from: http://jadejoddle.com/extoverts-introvertslearning-languages/) 


\section{Why Teacher Must Know About Learners' Learning Styles Preference}

Teachers' concern about learners' learning styles preference is one of the basic issues in the field of pedagogy. Any pedagogy is a cooperative and interactive process where both the teacher and the learners must have the knowledge about each other's styles of teaching and learning. If any gap of miscommunication occurs, the whole context of teaching/learning becomes vulnerable to collapse. The teaching approach of a teacher must be 'in tune with learners' psychological, cognitive and affective characteristics' (Ahmed 2014; p. 389). Ahmed also opines that the knowledge and ideas about students' preferred learning styles helps teachers adapt their teaching style to match with that of the students; it also serves as guidelines to the designs of the syllabus or curriculum (ibid).

Gilakjani (2012) observes that there must be a match between the teachers' teaching approach and the students' learning styles. Teaching is to be accommodated to learning styles to improve students' 'overall learning results, increases both motivation and efficiency and enables a positive attitude towards the language being learned'.Using learning styles ensures finding the best ways for both students to learn successfully and teachers to teach proficiently. (P. 110). As Riazi and Riasiti (2007) state, "to achieve a desired learning outcome, teachers should provide teaching interventions and activities that are compatible with the ways through which learners like to learn the language or any other subject matter (p. 98)." If this compatibility fails to happen, the language class is doomed to be unproductive.

For ensuring the interactive performance in the language classroom the teacher must know the learners' personal likes and dislikes regarding their learning styles. Synchronization must be maintained to ensure learners' maximum participation in the teaching / learning process. Classroom harmonization fails once the teacher fails to recognize and consider her learners' learning styles preferences. Therefore, classroom discussion becomes onesided making the learners cornered because without their absence of personal involvement, as the teacher does not recognize their preferred learning styles, the classroom teacher becomes all in all.

\section{Objectives of This Study}

The objective of the present study is to identify the learning styles preferred by the cadets of Sylhet Cadet College while learning English as a foreign language. The study attempts to answer the following question:

- What are the learning styles that the cadets prefer while learning English?

- How can the cadets be categorized based on their EFL learning styles?

\section{Methodology}

\section{Respondents}

The respondents were selected from the cadets of Sylhet Cadet College. They were 150 in number. All belong to the senior classes (X, XI \& XII).Senior cadets were selected as respondents because they were the most mature learners and had the most polished sense of personal learning styles preference. They are the most confident cadets amongst others.

\section{Materials}

To survey the learning styles preference of the cadets a questionnaire to the cadets was followed.The questionnaire was made consisting of eighteen questions. The questionnaire was also the answer paper. It was almost a structured questionnaire as the respondents had no scope for choosing any other options for answering, except those provided in the questionnaire.Necessary notes were taken during the questionnaire session.

\section{Data Preparation}

After the result found from the questionnaire, the collected data were typed on the computer. Then the data were thoroughly counted and analyzed. Data analysis was done based on meticulous study of the information collected from the questionnaire. As the researcher himself is a faculty member of Sylhet Cadet College and has fifteen months experience of teaching and observing the cadets, analysis and interpretation of the data was straightforward and authentic. Besides, the related literature review served as the guidelines for the data analysis. The communication language, including the language of the questionnaire, was English because cadets are already accustomed to communicating in English.

\section{Data Presentation and Analysis in Brief}

Table 1. Visual Learners.

\begin{tabular}{llllll}
\hline Statement & Always & $\begin{array}{l}\text { Very } \\
\text { often }\end{array}$ & Sometimes & Never & $\begin{array}{l}\text { Total } \\
\text { Respondents }\end{array}$ \\
\hline $\begin{array}{l}\text { I learn more } \\
\text { by reading } \\
\text { books than } \\
\text { by listening } \\
\text { to others. }\end{array}$ & 44 & 46 & 46 & 9 & \\
$\begin{array}{l}\text { I prefer } \\
\text { learning } \\
\text { from }\end{array}$ & 28 & 31 & 65 & 21 & 145 \\
teacher's \\
$\begin{array}{l}\text { writing on } \\
\text { the }\end{array}$ & $19.31 \%$ & $21.38 \%$ & $44.83 \%$ & $14.48 \%$ & \\
whiteboard. & & & & & \\
\hline
\end{tabular}

Table-1 shows that cadets' learning style does not completely go with the Visual category. $62.06 \%$ (always + very often) cadets learn more by reading books than by listening to others. But the rest of them chose the options 'sometimes' and 'never'. Besides, $69.31 \%$ cadets do not prefer learning from teacher's writing on the whiteboard so much.

In Table-2 we can see that most of the cadets are in Auditory category and they like to learn by watching TV, 
films, etc. Similarly, a number of them like listening lecture more than reading textbook. Here, 'Sometimes' and 'Never' categories deserve special attention.

Table 2. Auditory Learners.

\begin{tabular}{|c|c|c|c|c|c|}
\hline Statement & Always & $\begin{array}{l}\text { Very } \\
\text { often }\end{array}$ & Sometimes & Never & $\begin{array}{l}\text { Total } \\
\text { Respondents }\end{array}$ \\
\hline I like to learn & 102 & 16 & 24 & 3 & \multirow{4}{*}{145} \\
\hline $\begin{array}{l}\text { by watching } \\
\text { TV, films, etc. }\end{array}$ & $70.34 \%$ & $11.1 \%$ & $16.55 \%$ & $2.1 \%$ & \\
\hline $\begin{array}{l}\text { I like listening } \\
\text { lecture more }\end{array}$ & 42 & 57 & 36 & 10 & \\
\hline $\begin{array}{l}\text { than reading } \\
\text { textbook. }\end{array}$ & $28.97 \%$ & $39.31 \%$ & $24.83 \%$ & $6.9 \%$ & \\
\hline
\end{tabular}

Table 3. Kinesthetic Learners.

\begin{tabular}{llllll}
\hline Statement & Always & $\begin{array}{l}\text { Very } \\
\text { often }\end{array}$ & Sometimes & Never & $\begin{array}{l}\text { Total } \\
\text { Respondents }\end{array}$ \\
\hline $\begin{array}{l}\text { I learn more } \\
\text { from doing } \\
\text { exercises in } \\
\text { the class. }\end{array}$ & 28 & 53 & 52 & 12 & \\
$\begin{array}{l}\text { I learn best } \\
\text { when I }\end{array}$ & 44 & 44 & 50 & 7 & 145 \\
$\begin{array}{l}\text { participate in } \\
\text { class- } \\
\text { activities. }\end{array}$ & $30.34 \%$ & $30.34 \%$ & $34.48 \%$ & $4.83 \%$ & \\
\hline
\end{tabular}

Here, cadets are in mixed opinion regarding being classified as Kinesthetic.Exercises and other class- activities are to some extent attracted to them.

Table 4. Group Learners.

\begin{tabular}{llllll}
\hline Statement & Always & $\begin{array}{l}\text { Very } \\
\text { often }\end{array}$ & Sometimes & Never & $\begin{array}{l}\text { Total } \\
\text { Respondents }\end{array}$ \\
\hline $\begin{array}{l}\text { When I study } \\
\text { in a group I }\end{array}$ & 70 & 49 & 24 & 2 & \\
$\begin{array}{l}\text { understand } \\
\text { and learn } \\
\text { better. }\end{array}$ & $48.28 \%$ & $33.79 \%$ & $16.55 \%$ & $1.38 \%$ & 145 \\
\hline
\end{tabular}

Table 5. Individual Learners.

\begin{tabular}{llllll}
\hline Statement & Always & $\begin{array}{l}\text { Very } \\
\text { often }\end{array}$ & Sometimes & Never & $\begin{array}{l}\text { Total } \\
\text { Respondents }\end{array}$ \\
\hline $\begin{array}{l}\text { When I study } \\
\text { individually, I }\end{array}$ & 22 & 65 & 55 & 3 & \\
$\begin{array}{l}\text { understand and } \\
\text { learn better. }\end{array}$ & $15.17 \%$ & $44.83 \%$ & $37.93 \%$ & $2.1 \%$ & 145 \\
\hline
\end{tabular}

Most of the cadets prefer group learning. 48.28\% cadets can understand and learn better if they study in a group. From Table 4 and Table 5 we came to know that there are some cadets who belong to the both categories.

Table 6. Field Dependent Learners.

\begin{tabular}{llllll}
\hline Statement & Always & $\begin{array}{l}\text { Very } \\
\text { often }\end{array}$ & Sometimes & Never & $\begin{array}{l}\text { Total } \\
\text { Respondents }\end{array}$ \\
\hline $\begin{array}{l}\text { I like to } \\
\text { learn a }\end{array}$ & 13 & 27 & 49 & 56 & \\
$\begin{array}{l}\text { lesson as a } \\
\text { whole, not } \\
\text { step by step. }\end{array}$ & $8.96 \%$ & $18.62 \%$ & $33.8 \%$ & $38.62 \%$ & 145 \\
\hline
\end{tabular}

Table 7. Field Independent Learners.

\begin{tabular}{llllll}
\hline Statement & Always & $\begin{array}{l}\text { Very } \\
\text { often }\end{array}$ & Sometimes & Never & $\begin{array}{l}\text { Total } \\
\text { Respondents }\end{array}$ \\
\hline $\begin{array}{l}\text { I like to learn } \\
\text { a lesson step } \\
\text { by step. }\end{array}$ & 42 & 40 & 26 & 7 & \\
\hline
\end{tabular}

Most of the cadets are Field Independent. They prefer learning a lesson step by step.

Table 8. Inductive Learners.

\begin{tabular}{llllll}
\hline Statement & Always & $\begin{array}{l}\text { Very } \\
\text { often }\end{array}$ & Sometimes & Never & $\begin{array}{l}\text { Total } \\
\text { Respondents }\end{array}$ \\
\hline $\begin{array}{l}\text { I learn grammar } \\
\text { from examples } \\
\text { and uses in }\end{array}$ & 56 & 40 & 42 & 7 & \\
\begin{tabular}{l} 
sentences. \\
\hline
\end{tabular} & $38.62 \%$ & $27.59 \%$ & $28.96 \%$ & $4.83 \%$ & 145 \\
\hline
\end{tabular}

Table 9. Deductive Learners.

\begin{tabular}{llllll}
\hline Statement & Always & $\begin{array}{l}\text { Very } \\
\text { often }\end{array}$ & Sometimes & Never & $\begin{array}{l}\text { Total } \\
\text { Respondents }\end{array}$ \\
\hline $\begin{array}{l}\text { I first } \\
\text { learn/memorize } \\
\text { grammatical }\end{array}$ & 36 & 31 & 42 & 36 & \\
$\begin{array}{l}\text { rules, then see } \\
\text { their uses in } \\
\text { examples in } \\
\text { sentences. }\end{array}$ & $24.83 \%$ & $21.38 \%$ & $28.96 \%$ & $24.83 \%$ & 145 \\
\hline
\end{tabular}

The cadets who can be categorized as Inductive are a bit more in number. Otherwise, actually, a great number of them belong to the both categories. They prefer discovering grammatical rules from the text, as well as, follow the process of learning them at first.

Table 10. Authority Oriented / Communicative Learners.

\begin{tabular}{llllll}
\hline Statement & Always & $\begin{array}{l}\text { Very } \\
\text { often }\end{array}$ & Sometimes & Never & $\begin{array}{l}\text { Total } \\
\text { Respondents }\end{array}$ \\
\hline $\begin{array}{l}\text { I learn better } \\
\text { when my }\end{array}$ & 61 & 46 & 30 & 8 & \\
$\begin{array}{l}\text { teacher } \\
\text { guides me } \\
\text { directly and } \\
\text { explains } \\
\text { lessons. }\end{array}$ & $42.1 \%$ & $31.72 \%$ & $20.69 \%$ & $5.52 \%$ & 145 \\
\hline
\end{tabular}

It is important to mention that most of the cadets are authority-oriented. They expect that their teachers will guide them directly. Only $5.52 \%$ cadets do not like this.

Table 11. Extrovert/Introvert Learners.

\begin{tabular}{llllll}
\hline Statement & Always & $\begin{array}{l}\text { Very } \\
\text { often }\end{array}$ & Sometimes & Never & $\begin{array}{l}\text { Total } \\
\text { Respondents }\end{array}$ \\
\hline $\begin{array}{l}\text { I feel shy } \\
\text { while }\end{array}$ & 16 & 36 & 66 & 27 & \\
$\begin{array}{l}\text { speaking with } \\
\text { others in }\end{array}$ & $11.03 \%$ & $24.83 \%$ & $45.52 \%$ & $18.62 \%$ & 145 \\
\begin{tabular}{l} 
English. \\
\hline
\end{tabular}
\end{tabular}

Initially, it was expected that all the cadets would be negative in response to this statement. But, as the table shows, many cadets feel shy while speaking with others in English. 
Cadets are not so much extroverted as the finding reveals.

All the cadets like friendly teachers, though they are divided in choosing formal and informal teachers. But, remarkably, none of them likes the teachers who are formal and strict.
Table 12. Favored Type of Teacher.

\begin{tabular}{lllll}
\hline $\begin{array}{l}\text { Type of } \\
\text { teacher I }\end{array}$ & $\begin{array}{l}\text { Friendly\& } \\
\text { informal }\end{array}$ & $\begin{array}{l}\text { Friendly } \\
\text { but formal }\end{array}$ & $\begin{array}{l}\text { Formal } \\
\text { \& strict }\end{array}$ & $\begin{array}{l}\text { Total } \\
\text { Respondents }\end{array}$ \\
\cline { 2 - 5 } like most & 62 & 83 & Nil & 145 \\
\hline
\end{tabular}

Table 13. Learning New Vocabulary.

\begin{tabular}{llllll}
\hline \multirow{2}{*}{$\begin{array}{l}\text { To learn new } \\
\text { vocabulary I prefer }\end{array}$} & Guessing the meaning & $\begin{array}{l}\text { Using English-English } \\
\text { Dictionary }\end{array}$ & $\begin{array}{l}\text { UsingEnglish-Bangla } \\
\text { Dictionary }\end{array}$ & $\begin{array}{l}\text { Writing the words } \\
\text { several times }\end{array}$ & $\begin{array}{l}\text { Total } \\
\text { Respondents }\end{array}$ \\
\cline { 2 - 6 } & 68 & 45 & 26 & 6 & \\
& $46.9 \%$ & $31.03 \%$ & $17.93 \%$ & $4.14 \%$ & 145 \\
\hline
\end{tabular}

It is an important finding that a good number of cadets prefer to learn new vocabulary by guessing the meaning. Their next choice is using English- English dictionary.

Table 14. Moment of being Corrected by Teacher.

\begin{tabular}{lllll}
\hline \multirow{2}{*}{$\begin{array}{l}\text { When do I want to be corrected by } \\
\text { my teacher? }\end{array}$} & Instantly, in front of all & Later, at the end of lesson & Later, in private & Total Respondents \\
\cline { 2 - 5 } & 75 & 33 & 37 & 145 \\
\hline
\end{tabular}

It is a very positive finding that half the cadets are smart and courageous enough to be corrected by their teacher instantly in front of all. But there are a number of cadets $(25.52 \%)$ who do not want this and they prefer to be corrected later in private.

\section{Pedagogical Implications}

This research may be helpful for both teachers and the cadets.

- Teachers should consider that a great number of cadets like to learn English by watching television programs and films. Cadets should be allowed and exposed to the materials of visual learning of these sorts.

- Teachers should keep in mind that none of the cadets likes the teachers who are formal and strict in classroom. Whether formal or informal, teachers should be friendly.

- As most of the cadets prefer group learning, teachers need to organize the lesson contents in a way that perfectly contain the materials of group learning in classroom.

- Teacher should encourage the cadets to use their cognitive and intuitive capacity to learnnew vocabulary at first. It is because a great number of cadets prefer learning a new word by guessing the meaning first.

- It is very important to remind the language teachers that the system of correcting the cadets' mistakes instantly should not be over- generalized because in the finding $25.52 \%$ cadets prefer to be corrected later in private. They may feel shy if the teacher corrects their mistakes instantly in front of all.

- Teacher should consider that the cadets like to be authority-oriented while learning English. They expect their teachers' direct supervision and guidance.

- A significant number of cadets feel shy while speakingin English with others. Teachers should pay special concentration to them to reduce their level of anxiety and shyness.

\section{Conclusion}

A perfect match between the teacher's teaching style and the learners' learning style is a must for the successful outcome of a language class. Otherwise, if the teacher remains ignorant of the preferred learning styles her learners, the whole teaching context will result in confusion and ineffectuality. The present study attempts to shed light on this basic issue in teaching English and exposes the learning styles of the senior cadets. The findings of the study can be used by the language teachers to be well known regarding the cadets' personal likes and dislikes while learning English. It can also be used for further innovation in syllabus design and curriculum development.

\section{Acknowledgment}

I am grateful to Cdr Md Saifur Rahman, (TAS), psc, BN, the principal of Sylhet Cadet College, for his support to carry out the research and permission to publish it in a journal. I offer my gratitude to some of my colleagues who helped me in this survey by giving valuable suggestions to improve the standard. I also offer thanks to my respondent cadets who willingly participated in the survey though time was very hectic then.

\section{Appendix}

\section{Questionnaire}

Dear cadets,

Good day! This is simply a research questionnaire. It has no connection with any of your examinations. Please read the following statements and respond to them based on how you learn English. Thanks a lot. 


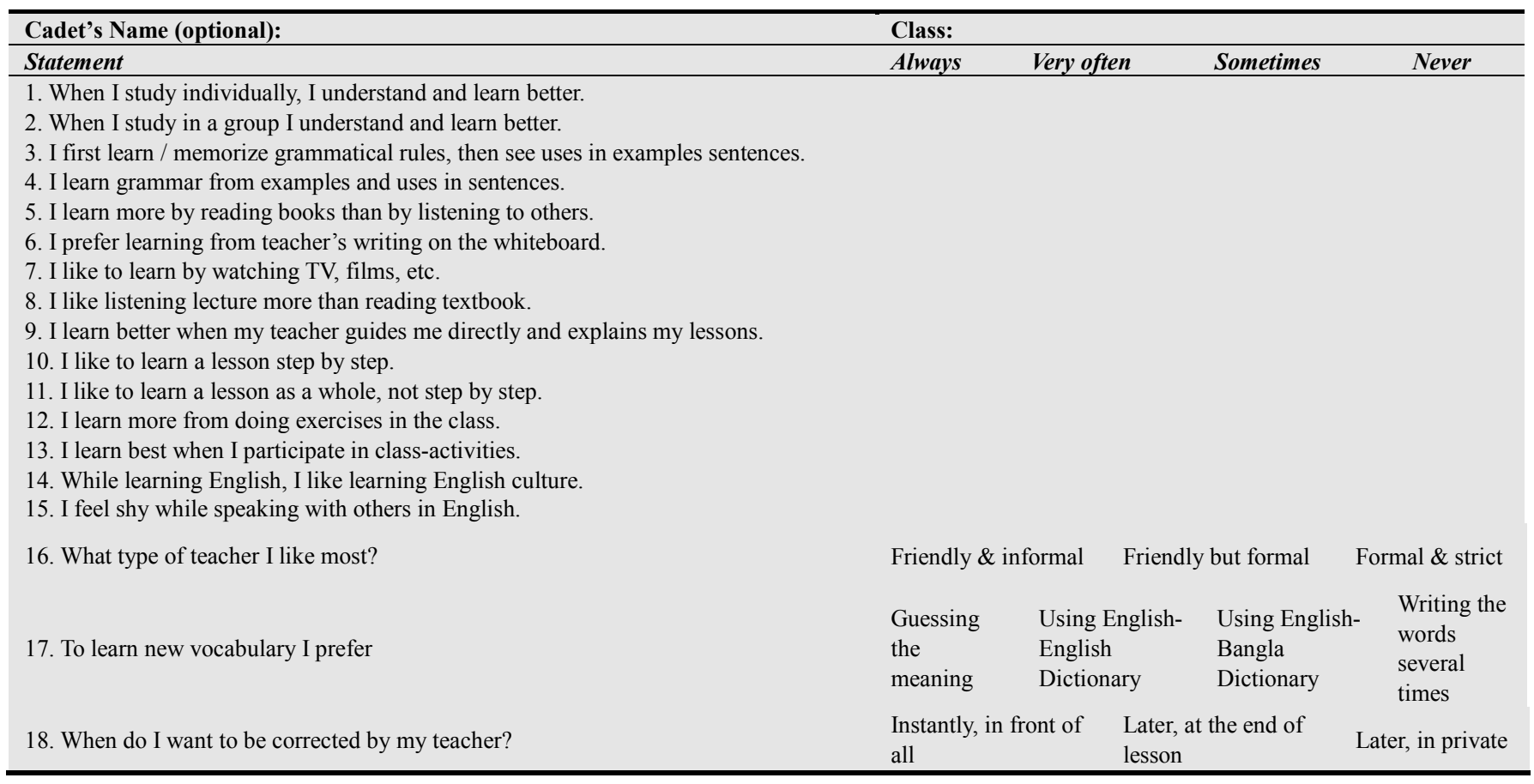

\section{References}

[1] Ahmed, Shaila. (2014) ESL/EFL Learning Style Preference among Bangladeshi Students. Language in India, 14 (12): 388-397.

[2] Dunn, R. and Dunn, K. (1978) Teaching students through their individual learning styles: A practical approach. NJ: RestonBook.

[3] Fleming, N.D. (2001) Teaching and learning styles: VARK strategies. New Zealand: Christchurch.

[4] Gilakjani, Abbas Pourhossein. (2012) Visual, Auditory, Kinaesthetic Learning Styles and Their Impacts on English Language Teaching. Journal of Studies in Education, 2 (1): 104-113.

[5] Huda, Mohammad Emdadul. (2013) Learning Style Preferences of EFL Learners at Higher Secondary Level in Bangladesh. Global Journal of Human Social Science: Linguistics \& Education, 13 (11): 22-50.

[6] Islam, Md. Jahurul. (2011) Language Learning Style Preferences: Bangladeshi EFL Learners. Harvest: Jahangirnagar Studies in Language and Literature, 26.

[7] Kara, Selma. (2009) Learning Styles and Teaching Styles: A Case Study in Foreign Language Classroom. Conference of the International Journal of Arts and Sciences, 1(20): 77-82.
[8] McLeod, S. A. (2013) Kolb - Learning Styles [Accessed 12 December 2015] Available from World Wide Web: www.simplypsychology.org/learning-kolb.html.

[9] Nunan, D. (1991) Language teaching methodology. New York: Prentice Hall.

[10] Ramezani, Afsaneh Effatdokht et al. (2015) An Exploratory Study of the Language-learning Style Preferences of Iranian EFL High School Students. Advances in Language and Literary Studies, 6 (2): 151-159.

[11] Riazi, Abdolmehdi and Riasiti, M. Javad. (197) Language Learning Style Preferences: A Students Case Study of Shiraz EFL Institutes. The Asian EFL Journal Quarterly, 9 (1): $97-$ 125 .

[12] Reid, J. M. (1997) The learning style preferences of ESL students. TESOL Quarterly, 21: 87-111.

[13] Reid, J.M. (1995) Learning styles in the ESL/EFL classroom. Boston: Heinle \& Heinle.

[14] Sharp, A. (2004) Language learning and awareness of personality type in Chinese settings [Accessed 10 December 2015] Available from World Wide Web: http://www.asianefljournal.com/Article_1_June_as_2004.pdf.

[15] Stern, M.H. (1983) Fundamental Concepts of Language Teaching. New York: Oxford University Press.

[16] Vaseghi, Reza et al. (2012) Language Learning Style Preferences: A Theoretical and Empirical Study. Advances in Asian Social Science, 2 (2): 441-452. 